\title{
\#4
}

\section{Mungkinkah Menyandingkan Idealisme dan Bisnis Media?}

\author{
Arba'iyah Satriani
}

Dunia sedang berubah dengan cepat karena kemajuan teknologi yang pesat. Perusahaan media mengalami disrupsi yang luar biasa di tengah kemajuan teknologi tersebut. Disrupsi teknologi ini ditambah dengan situasi pandemi yang sudah berlangsung sejak 2020 silam. Dalam concept note Hari Kebebasan Pers Sedunia 2021, diungkapkan bahwa banyak perusahaan media mengalami tantangan finansial yang substantif di era ini. Hal tersebut mau tidak mau mempengaruhi keberlangsungan hidup media termasuk para awak medianya.

Lalu, bagaimana eksistensi nilai-nilai jurnalisme (journalism values) dan idealisme jurnalis di tengah berbagai tantangan tersebut sementara perusahaan media harus tetap bertahan? Untuk menjawab pertanyaan tersebut, kita perlu menjawab pertanyaan lain, apakah jurnalisme masih diperlukan? Apakah qualified 
journalism masih menjadi hal yang penting bagi publik saat mereka mencari informasi?

\section{Jurnalisme Di Tengah Serbuan Media Sosial}

Jurnalisme adalah kegiatan mengumpulkan, menilai, menciptakan serta menampilkan berita dan informasi. Jurnalisme dapat dibedakan dari aktivitas lain secara jelas dengan melihat karakteristik dan praktik yang dijalankan (What is journalism, 2021). Jadi inti dari jurnalisme adalah mengumpulkan dan mendistribusikan informasi sehingga publik mengetahuinya. Sedangkan menurut Kovach dan Rosenstiel (2006) publik perlu kinerja jurnalisme untuk membantu memutuskan sesuatu dalam hidupnya. Karena itu, sampai kapanpun, jurnalisme tetap diperlukan oleh masyarakat, meskipun medium pengantarnya bisa berbeda tergantung zaman dan teknologi yang berkembang.

Sebagian pihak menilai, jurnalisme saat ini mendapat tantangan dari media sosial yang menumbuhsuburkan praktik citizen journalism (jurnalisme warga). Tanpa peran jurnalis dan media massa, masyarakat bisa mendapatkan informasi karena masyarakat dapat memproduksi konten informasi tersebut. Bahkan tanpa perlu proses yang njlimet dan panjang seperti di perusahaan media, informasi yang diproduksi masyarakat bisa disebarkan dengan segera. Namun justru di situlah letak perbedaannya.

Seperti diungkapkan oleh Kovach dan Rosenstiel (2006), media massa harus menerapkan prinsip verifikasi sebelum mempublikasikan informasi yang diperolehnya. Artinya, informasi yang disebarkan oleh media massa sudah melewati tahap pengecekan kepada berbagai sumber, sebelum disebarluaskan. Inilah yang seringkali tidak dilakukan oleh pelaku jurnalisme warga. Selain itu, reputasi atau nama besar sebuah media massa seringkali menjadi faktor yang mempengaruhi tingkat kepercayaan masyarakat. Bandingkan dengan produk jurnalisme warga yang 
produsennya tidak dikenal atau diketahui. Di sinilah peran jurnalisme masih diperlukan.

\section{Jenis Informasi}

Jika menilik bentuk dan format informasi yang diperlukan oleh publik maka informasi tersebut akan sangat beragam. Di masa lalu media massa menentukan informasi yang diperlukan oleh publik. Namun saat ini, ketika internet dapat mewadahi komunikasi dua arah serta dapat menyebarkan informasi secepat mungkin maka jenis informasi yang diperlukan oleh masyarakat tak lagi dapat dideteksi dengan mudah. Karena peran media massa di masa lalu, yang menentukan informasi yang harus dikonsumsi masyarakat, muncullah teori seperti jarum hipodermik dll yang di masa ini telah berubah kondisinya (Wildan, 2018).

Saat ini masyarakat memutuskan sendiri informasi yang diperlukan, informasi yang perlu disebarkan dan informasi yang menarik bagi mereka. Hal ini menjadi tantangan besar bagi industri media massa. Apalagi, masyarakat merasa tak lagi memerlukan medium yang dikelola perusahaan media untuk menyebarkan informasi yang dianggap penting itu. Masyarakat, melalui akun media sosial yang dimilikinya, dapat dengan mudah menyebarkan informasiinformasi yang dipilihnya. Dengan sekali tekan di layar gawai mereka, informasi itu sudah terdistribusikan ke segala penjuru dunia dalam hitungan detik saja.

Kondisi ini menyebabkan media massa (terutama) arus utama, harus menyesuaikan diri dan mengubah strateginya. Mungkin itu sebabnya, kita saat ini akan dengan mudah menemukan informasiinformasi 'receh' di media massa besar yang dipublikasikan secara online. Prinsip media online adalah kecepatan sehingga apapun yang berkembang dan menjadi perbincangan masyarakat (viral) maka media massa online merasa harus memuatnya juga. Tujuannya adalah untuk memperoleh lebih banyak pengunjung 
(netizen) yang pada akhirnya akan mempengaruhi perolehan pendapatan media tersebut.

\section{Bisnis Unik Media}

Bisnis memang tak bisa dipisahkan dari industri media. Hal ini dikarenakan media massa memerlukan pasokan dana yang memadai agar dapat menjalankan usahanya dengan baik. Media massa adalah bisnis yang unik karena mencampurkan antara idealisme dan kebutuhan untuk memperoleh profit. Di sini, perusahaan media harus berhati-hati menyeimbangkan keduanya agar tetap bisa tampil elegan dan bermanfaat bagi masyarakat.

Kenyataannya, menjalankan bisnis media massa bukan sesuatu yang mudah. Berita dan informasi yang disampaikan media massa tidak boleh sembarangan. Dalam dunia jurnalistik, kita mengenal nilai-nilai jurnalisme, elemen jurnalisme juga kode etik jurnalis yang harus diterapkan dalam praktik pengelolaan isi media yang benar. Bahwa kualitas produk jurnalistik saat ini jauh lebih cair dibandingkan dengan di masa lalu, mungkin benar adanya. Namun hal tersebut tidak mengubah kenyataan bahwa media massa harus menjaga kualitas publikasinya jika ingin mendapat tempat di hati publik. Media massa yang baik tetap menjadi rujukan utama bagi masyarakat dalam mencari informasi.

Di sisi lain, untuk memproduksi konten yang berkualitas diperlukan sumber daya yang mumpuni. Artinya diperlukan biaya yang tidak sedikit untuk menghasilkan produk (berita dan informasi) yang berkualitas. Sementara selama ini masyarakat dimanjakan dengan ketersediaan informasi yang relatif serbagratis di internet. Maukah masyarakat membayar untuk mendapatkan informasi yang berkualitas?

Jika menilik beberapa survei yang dilakukan di beberapa negara, seperti dilaporkan oleh situs digitalnewsreport.org, kecenderungan 
orang untuk membayar berita dari media online, meningkat dari tahun ke tahun (Fletcher, 2020). Di Amerika dan di Inggris, alasan masyarakat bersedia membayar media berita online dengan cara berlangganan adalah (1) konten yang disajikan lebih berkualitas dibandingkan dengan informasi yang diperoleh secara gratis; (2) ada jurnalis-jurnalis tertentu yang disukai tulisannya/laporannya; (3) memerlukan informasi tertentu yang terkait dengan pekerjaan mereka dan itu tidak disediakan secara gratis di internet (Philips, 2018).

Sementara itu, beberapa media massa di Indonesia yang mempunyai platform digital bisa mendapatkan keuntungan dari konten premium, seperti yang dilakukan oleh Jakarta Post (Adam, 2018). Begitu pula dengan Tempo yang mengalami kenaikan pelanggan hingga seribu persen selama setahun (2016 ke 2017). Ini sebuah kabar gembira.

Media massa lain di Indonesia juga sudah menerapkan ketentuan berlangganan konten secara online antara lain Kompas.com dan Republika online. Namun belum ada riset menyeluruh dan memadai mengenai kecenderungan tersebut. Meski demikian, langkah ini bisa jadi merupakan suatu terobosan yang bisa dilakukan untuk menjawab pertanyaan mengenai menjaga kualitas media. Apalagi jika menilik hasil survei di Amerika dan Inggris yang menunjukkan bahwa para pembaca media online tetap bersedia berlangganan berita secara online karena alasan-alasan tertentu.

Memang masyarakat Indonesia banyak yang belum siap untuk membayar informasi dari media massa online. Seperti yang dikatakan oleh Riyadi (Jakarta Post) yang dikutip dalam artikel di Tirto.id. la mengatakan bahwa orang Indonesia jika diberi (berita) secara cuma-cuma akan dibaca. Namun jika diminta membayar meskipun dalam jumlah relatif kecil, orang Indonesia tidak mau. Hal 
ini terjadi karena keterlambatan media menyadari perubahan bisnis digital sehingga media pun terlambat mengantisipasinya.

Namun sekali lagi, kenyataan tersebut bukan berarti tidak ada harapan untuk menerapkan kebijakan konten berbayar oleh media. Survei di Amerika Serikat pada 1999 terhadap 64 surat kabar online yang melayani California, Texas, New York, dan Florida menunjukkan bahwa metode berlangganan konten kurang diminati (Chyi \& Sylvie 2001 dalam Chyi, 2005). Alasannya menurut Borrel \& Associates (2001 dalam Chyi, 2005) adalah cukup banyak situs yang memberikan informasi secara cuma-cuma. Jadi, untuk apa membayar konten yang bisa diperoleh secara gratis. Namun ternyata situasi ini berubah beberapa tahun belakangan.

Laporan dari situs Voice of America menunjukkan bahwa tren paywall (konten berbayar) telah menyebar ke seluruh dunia. Salah satu penyebabnya adalah para pemasang iklan memprotes biaya iklan di internet yang diterapkan oleh pengelola media demi mempertahankan jurnalisme berkualitas (Jones, 2013). Sekali lagi, ini adalah sebuah peluang bagi media untuk tetap menjaga kualitas dan eksistensinya.

Di sisi lain, saat ini kita menyaksikan perkembangan media online yang dipelopori oleh Kumparan.com. Media ini melakukan kolaborasi dengan media di daerah untuk mengisi konten. Selain itu, disediakan pula peluang bagi individu untuk menulis secara rutin di Kumparan.com dengan menjadi penulis tetap dalam rubrik semacam blog tetapi dikelola oleh manajemen Kumparan.com. Langkah ini kemudian diikuti oleh beberapa media lain seperti pikiran-rakyat.com.

Media-media kecil bergabung dengan media besar. Media kecil mendapat "nama besar" media yang sudah dikenal luas oleh masyarakat sementara media besar mendapat keuntungan dengan 
luasnya pembaca mereka serta beragamnya konten yang disampaikan, tanpa mengeluarkan biasa investasi yang besar.

Media besar yang menjadi payung (media payung) bagi mediamedia kecil ini melakukan pembinaan terhadap media-media kecil, kemudian melakukan perjanjian kesepakatan mengenai berbagai hal teknis. Namun pertanyaannya, bagaimana menjaga kualitas media besar ini?

Tentu saja, pada awal kerja sama, ada pelatihan untuk menjelaskan mengenai eksistensi media payung dan kinerja secara umum, etika yang harus dijaga dan seterusnya. Hanya saja, dalam aktivitas yang padat dan dinamis, apakah kualitas media payung yang sudah mentradisi dan dijaga selama ini dapat

selalu diikuti oleh media-media subordinatnya?

Penurunan kualitas konten di media payung tentu akan berpengaruh pada reputasinya. Bagaimanapun, nama besar selalu bersanding dengan reputasi dan kualitas. Jika pilihan untuk mengembangkan inovasi bisnis model ini dipilih, media payung harus melakukan pemantauan yang ketat terhadap kualitas konten dari media-media di bawahnya. Selain itu, media payung juga harus memberikan pelatihan yang terus-menerus sebagai salah satu upaya untuk memastikan bahwa media subordinatnya selalu dalam koridor etika publikasi yang sesuai aturan.

\section{Perpaduan Idealisme dan Kualitas}

Karena itu, pilihan untuk menerapkan inovasi bisnis media berlangganan menjadi opsi yang lebih tepat. Praktik ini nyaris sama dengan model berlangganan koran di masa lalu. Para pengelola media, dapat mempertahankan kualitas media massa yang dikelolanya, menjaga idealisme jurnalisnya serta tetap bisa bertahan dalam persaingan di era disrupsi ini. 
Tentu saja, diperlukan kreativitas yang tak terbatas untuk mengimplementasikan model-model bisnis berlangganan konten media ini. Misalnya, pembaca bisa memutuskan untuk berlangganan per minggu, per bulan atau per tahun. Bonus-bonus yang diberikan untuk para pemilih jenis langganan juga bisa dibuat semenarik mungkin. Untuk menentukan bonus ini perlu dilakukan survei publik untuk mengetahui hal-hal yang diminati masyarakat atau hal-hal yang diperlukan masyarakat.

Misalnya, saat ini kita menghadapi era pandemi dan sebagian aktivitas dilakukan secara online seperti webinar. Karena itu, diperlukan supporting items bagi kegiatan webinar sehingga bisa menjadi bonus yang menarik bagi para pelanggan, seperti lampu ring light lamp, earphone dll.

Langkah lain yang diperlukan untuk mendukung model bisnis berlangganan konten ini adalah kemudahan cara pembayaran. Para pelanggan jangan direpotkan dengan urusan pembayaran yang rumit atau terbatas. Perusahaan media sedang bersaing untuk memenangkan hati pelanggan sehingga selayaknya calon pelanggan atau pelanggan setia dimanjakan dengan berbagai kemudahan cara pembayaran.

Tampilan layar yang menarik dan mudah diakses juga menjadi keunggulan yang perlu diprioritaskan. Perusahaan media harus memastikan bahwa situs mereka bisa dibuka dari manapun dan kapanpun. Mobilitas yang tinggi dari publik di era serba digital ini membuat situs yang mudah diakses akan menjadi pilihan karena tidak dibatasi oleh buruknya kualitas jaringan.

Yang berikutnya perlu dipertimbangkan adalah keterikatan (engagement) dengan konsumen media. Di masa lalu, media massa menentukan hal-hal yang penting bagi publik tanpa mendapatkan umpan balik langsung. Namun di era internet saat ini, berita atau informasi yang didistribusikan kepada khalayak akan mendapat 
respon segera setelah informasi itu disampaikan. Publik bukan orang bodoh, mereka mempunyai pendapat yang perlu didengar sehingga perlu disediakan ruang diskusi bagi mereka. Namun, diskusi ini tak sekadar diberi ruang tetapi harus dimoderasi dengan menempatkan orang yang paham jurnalistik dan memiliki kemampuan komunikasi yang baik, untuk menjadi perantara.

Kehadiran moderator yang baik akan menjadi jalan bagi terciptanya diskusi publik yang sehat dan memberikan solusi. Ini yang belum dikerjakan secara optimal oleh pengelola media massa selama ini. Komentar berita yang dimoderasi kemudian dikelola dengan baik oleh orang yang kompeten, akan menjadi nilai tambah media massa. Harus disadari bahwa di masyarakat, terdapat sebagian orang yang merasa perlu untuk berkontribusi dengan memberikan komentar. Bahkan kadang-kadang, ide sumber berita bisa diperoleh dari ruang diskusi pembaca ini.

Selain hal-hal teknis yang perlu dipersiapkan untuk menyambut para pelanggan konten media, yang paling utama adalah memastikan bahwa informasi yang disampaikan di media berbayar ini bukan informasi murahan, bukan informasi yang "hanya begitu saja". Konten media harus dibedakan dengan media-media online gratis yang menyampaikan kilasan informasi saja. Jika konten berkualitas hanya bisa diperoleh dari media yang berbayar maka publik akan melanggan konten media tersebut. Tidak ada pilihan lain.

Namun kendala untuk menampilkan produk yang berkualitas telah menjadi persoalan yang terus menjadi bahan diskusi. Di antaranya adalah akurasi yang lemah, baik penulisan maupun informasinya. Kemudian pilihan narasumber yang ditampilkan, kadang tidak relevan dengan isu yang disampaikan. Hal ini akan menurunkan kualitas produk media. 
Akurasi yang lemah seringkali terjadi karena rutinitas jurnalis yang didukung oleh lemahnya pemantauan oleh ruang redaksi media. Para jurnalis di lapangan merasa bahwa kegiatan meliput seharihari adalah sebuah rutinitas yang biasa dilakukan. Perasaan seperti ini mengurangi semangat untuk menampilkan yang terbaik. Karena itu, kesalahan ketik atau sedikit kekeliruan informasi yang disampaikan, kerap dianggap sebagai suatu yang biasa. Inilah yang perlu dihindari. Kegiatan upgrading teknik jurnalistik bagi jurnalis menjadi solusi yang bisa dilakukan.

Rutinitas juga membuat sebagian jurnalis merasa malas untuk mengembangkan diri. Merasa sudah berada di situasi yang sama bertahun-tahun membuat daya kritis kadang menurun atau malah hilang. Karena itu, rotasi jurnalis menjadi solusi dari perusahaan media. Dengan berpindah atau beralih bidang liputan, jurnalis akan dipaksa untuk mengenali medan liputan yang baru. Dari sana muncul rasa ingin tahu yang lebih tinggi.

Cara lain adalah dengan membandingkan berita yang dimuat di media lain lalu mengkajinya. Kegiatan ini bisa saja dilakukan sendiri oleh sang jurnalis. Namun jika hal tersebut sulit dilakukan maka perusahaan media harus memfasilitasinya: membentuk ruang diskusi internal secara berkala dan menghadirkan para pakar di bidangnya. Dengan begitu, diharapkan para jurnalis akan terpacu untuk selalu memperbaiki diri dan mencari narasumbernarasumber yang sesuai dengan bidang liputannya.

Daya bersaing antar jurnalis juga harus dimunculkan sehingga berita yang terbaiklah yang akan muncul. Budaya kloning berita yang telah sedemikian lekat harus dihentikan dengan berbagai cara karena ini salah satu sumber kemalasan jurnalis.

Tentu saja, semua langkah itu harus disertai dengan penghargaan yang memadai bagi jurnalis, baik dari sisi kesejahteraan maupun dari sisi eksistensi mereka. Meskipun jurnalis adalah bagian dari 
"ruang produksi" tetapi mereka bukan buruh yang seperti kita temui di pabrik-pabrik. Jurnalis adalah seorang intelektual yang mengembangkan informasi dengan daya pikir dan daya nalarnya sehingga penghargaan yang diberikan haruslah sebanding.

Kembali pada pertanyaan di awal tulisan, maka idealisme jurnalis bisa berjalan seiring dengan inovasi bisnis media. Namun diperlukan langkah kreatif yang out of the box untuk melakukannya. Diperlukan pula kesadaran yang sama mengenai pentingnya jurnalisme, pentingnya jurnalisme yang berkualitas, dan pentingnya menjaga independensi jurnalis. Tanpa itu semua, bisnis media model apapun hanya menjadi wacana belaka.

\section{Referensi}

Adam, Aulia (2018, 9 Februari). Benarkah Bisnis Media Online tak secerah Masa Depan Internet. Tirto.id. Diakses dari https://tirto.id/benarkah-bisnismedia-online-tak-secerah-masa-depan-internet-cEv5

Fletcher, Richard. (2020). How and Why People are Paying for Online News. Diakses dari https://www.digitalnewsreport.org/survey/2020/how-andwhy-people-are-paying-for-online-news/

Hakim, Wildan (2018) Jurnalisme Berkualitas sebagai Model Bisnis Media Online: Analisis Deskriptif pada Situs Berita Tirto.id. FISIP Undana. Proceedings Seminar Nasional Fantasi Multikultur. HIm. 125-134.

Hsiang Iris Chyi (2005) Willingness to Pay for Online News: An Empirical Study on the Viability of the Subscription Model, Journal of Media Economics, 18:2, 131-142, DOI: 10.1207/s15327736me1802_4

Jones, Aiden. (2013, 3 Juni). Survei Makin Banyak orang yang mau membayar akases untuk berita. Diakses dari https://www.voaindonesia.com/a/survei-makin-banyak-orang-maumembayar-untuk-akses-berita/1673884.html

Kovach, Bill., Tom Rosenstiel. (2006). Sembilan Elemen Jurnalisme. Jakarta: Yayasan Pantau. 
Philips, Mary-Katharine. (2018, 6 Desember). What Makes Readers Pay for Online News. Diakses dari https://www.journalism.co.uk/news/what-makesreaders-pay-for-online-news-/s2/a731497/

What is Journalism (2021). Diakses dari https://www.americanpressinstitute.org/journalism-essentials/what-isjournalism/

\section{Profil Penulis}

Arba'iyah Satriani adalah dosen di Fakultas Ilmu Komunikasi Universitas Islam Bandung (Fikom Unisba) sejak 2011. la menyelesaikan pendidikan S1 di Universitas Brawijaya Malang. Pendidikan S2 dengan jurusan Journalism and Mass Communication diselesaikan di Griffith University Australia yang ditempuh dengan beasiswa Australian Development Scholarships (ADS) dari Pemerintah Australia. Sebelum menjadi dosen, Arba'iyah Satriani yang akrab disapa Aan ini adalah wartawan di Harian Umum Republika dan pernah menjadi koresponden di Tempo online. Sebagai jurnalis, ia mendapatkan fellowship dari Asia Journalism Fellowship (AJF) di Nanyang Technological University (NTU) Singapura selama tiga bulan (2011). Selain mengajar, ia menjadi pengelola Jurnal Komunikasi MediaTor milik Fikom Unisba dan menjadi tutor online di Universitas Terbuka (UT). Hingga kini ia masih aktif menulis dan tulisannya dimuat di beberapa media nasional, lokal dan media berita online. 